\title{
EXPLORE
}

\section{Framework Information Technology Infrastructure Library (Itil V3) : Audit Teknologi Informasi Sistem Informasi Akademik (Siakad) Perguruan Tinggi}

\author{
Retno Dwi Handayani, RZ Abdul Aziz \\ Program Studi Sistem Komputer, Fakultas Ilmu Komputer \\ Institut Informatika dan Bisnis Darmajaya \\ Bandar Lampung, Indonesia \\ retnodh84@darmajaya.ac.id,rz_aziz@darmajaya.ac.id
}

\begin{abstract}
Purpose of this study is to provide convenience to XYZ University to determine performance or quality of information technology services Academic Information System information used by comparing the level of maturity of information technology current conditions (Current Maturity) and conditions to come (Expected Maturity), the results is a gap analysis and recommendations for improving quality of information technology services. Information technology audits at universities are used to determine the capability of information technology used. This information technology audit uses the ITIL V.3 framework, because the method is easier to use and provides recommendations to improve the performance of information technology to increase stakeholder satisfaction, we made the object of information technology audit at XYZ University an Academic Information System (SIAKAD). The data in this study obtained through direct observation to XYZ University by interviewing the developer and users of information technology and distributing questionnaires
\end{abstract}

Keyword : Information Technology Audit, Gap Analysis, ITIL V3, Maturity Level

\begin{abstract}
Abstrak-Tujuan dari penelitian ini adalah memberikan kemudahan kepada Perguruan Tinggi XYZ untuk mengetahui kinerja ataupun kualitas layanan teknologi informasi Sistem Informasi Akademik yang digunakan dengan cara membandingkan tingkat kematangan teknologi informasi kondisi saat sekarang (Current Maturity) dan kondisi yang akan datang (Expected Maturity), hasilnya merupakan gap analisis dan rekomendasi-rekomendasi untuk perbaikan kualitas layanan teknologi informasi. Audit teknologi informasi pada Perguruan Tinggi digunakan untuk mengetahui kapabillitas teknologi informasi yang digunakan. Audit teknologi informasi ini menggunakan framework ITIL V.3, dengan alasan metode tersebut lebih mudah digunakan dan memberikan rekomendasi untuk memperbaiki kinerja teknologi informasi guna meningkatkan kepuasan stakeholder, kami menjadikan objek audit teknoogi informasi di Perguruan Tinggi XYZ adalah Sistem Informasi Akademik (SIAKAD). Data pada penelitian ini diperoleh melalui observasi langsung ke Perguruan Tinggi XYZ dengan wawancara ke bagian pengembang dan pengguna teknologi informasi dan menyebarkan kuesioner.
\end{abstract}

Kata Kunci : Audit Teknologi Informasi, Gap Analysis, ITIL V3, Maturity Level

\section{Pendahuluan}

Teknologi Informasi (TI) yang kembang pesatnya telah mengubah pola dan cara aktivitas suatu organisasi[1]. Faktanya, ketergantungan kepada TI untuk mencapai tujuan strategi dan kebutuhan organisasi menjadi pendorong utama dikarenakan mampu meningkatkan produktivitas, menjadikan proses bisnis menjadi efektif dan efisien[2].

Perguruan Tinggi XYZ mempunyai teknologi informasi yang sudah terintegrasi dan cukup besar dalam mengatur kegiatan akademik salah satunya, Sistem Informasi Akademik (SIAKAD) diharapkan mampu

meningkatkan kinerja dalam kegiatan akademik di Perguruan Tinggi tersebut maka audit teknologi informasi ini digunakan untuk memeriksa secara sistematis dengan bagian-bagian terkait pengembang dan pengguna teknologi informasi. Tujuannya mengevaluasi apakah sistem yang digunakan sudah dijalankan dengan baik dan benar.

Audit TI Sistem Informasi Akademik (SIAKAD) ini menggunakan ITIL V.3, metode tersebut mudah digunakan dan dapat memberikan rekomendasi untuk 
perbaikan kinerja teknologi informasi guna meningkatkan kepuasan stakeholder.

Information Technology Infrastructure Library (ITIL V3) merupakan kerangka kerja, suatu konsep yang menggambarkan praktek terbaik (best practice) manajemen layanan teknologi informasi (TI), berfokus pada pengembangan serta pengukuran terus menerus terhadap kualitas layanan IT yang diberikan terhadap bisnis atau pelanggan[9]. Tujuannya ialah memberikan kontribusi serta keuntungan dalam menjalankan teknik dan proses pada organisasi [6].

Tujuan dari penelitian adalah untuk memberikan gambaran kemudahan kepada perguruan tinggi/organisasi/perusahaan untuk pengukuran kualitas layanan teknologi informasi yang sedang/akan digunakan dengan cara membandingkan tingkat kematangan teknologi informasi kondisi saat sekarang dan kondisi yang akan datang sehingga diperoleh gap analisis dan rekomendasi-rekomendasi untuk perbaikan kualitas layanan teknologi informasi.

\section{Dasar Teori}

Audit Sistem Informasi (SI)/TI adalah proses mengumpulan, mengevaluasian bukti untuk menentukan apakah sistem informasi dapat melindungi aset, sudahkah TI memelihara integritas data sehingga keduanya diarahkan ke pencapaian tujuan bisnis yang efektif dengan cara penggunaan sumberdaya yang efisien [11].

Audit SI sebagai audit tersendiri, terpisah dari audit laporan keuangan, dilakukan untuk memeriksa tingkat kematangan, kesiapan suatu organisasi dalam melakukan pengelolaan teknologi informasi (IT governance). Tingkat kesiapan (level of maturity) dilihat dari tata kelola informasi, tingkat kepedulian seluruh stakeholders tentang posisi sekarang dan arah yang diinginkan di masa akan datang. Sehingga perencanaan TI dilakukan tidak asal-asalan. [4]

Information Technology Infrastructure Library (ITIL), kerangka kerja (Framework) yang dikembangkan oleh Office of Government Commerce (OGC) di Inggris. ITIL adalah sebuah pendekatan manajemen pelayanan IT yang paling banyak diterima diseluruh dunia, juga merupakan sekumpulan best practice dari manajemen pelayanan IT konsisten dan menyeluruh yang menyajikan pendekatan berkualitas pencapaian efektiv dan efisien dalam penggunaan sistem informasi disebuah lingkungan bisnis, juga merupakan framework yang dapat dikembangkan dan diadaptasikan dalam pengembangan suatu sistem [7]

Framework ITIL V3 terdiri atas 5 komponen yaitu, Service Strategy, Service Design, Service Transition, Service Operation dan Continual Service Improvement [3]. Ke lima bagian dari komponen ITIL V3 dijelaskan pada gambar 1.

a. Service Strategy memberikan panduan pengimplementasian IT, bagaimana memandang konsep IT bukan sebagai sebuah kemampuan organisasi (dalam memberikan, mengelola serta mengoperasikan layanan TI), tetapi juga sebagai sebuah aset strategis. Panduan ini disajikan dalam bentuk prinsip dasar dari konsep IT, acuan serta proses inti yang beroperasi di keseluruhan tahapan ITIL Service Lifecycle [10]. Proses yang dicakup dalam Service Strategy, di samping topik-topik diatas adalah, Service Portfolio Management, Financial Management dan Demand Management.

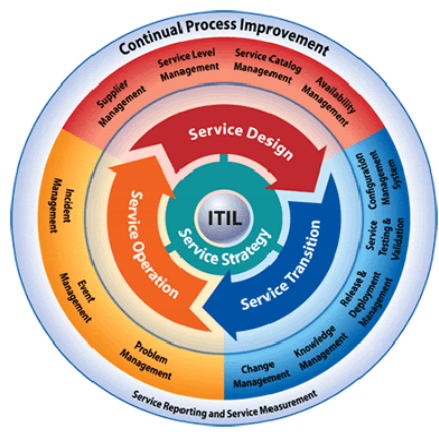

Gambar 1. Komponen ITIL V3

b. Service Design (SD) sebagai panduan kepada organisasi TI cara sistematis dan best practice dalam mendesain, membangun layanan TI maupun implementasi IT [10]. Service design merupakan prinsip dan metode yang menerjemahkan tujuan strategis organisasi TI dan bisnis, menjadi portofolio/koleksi layanan TI serta aset-aset layanan, seperti server, storage dan sebagainya. sub - domain service design. [5]. Proses yang dicakup dalam Service Strategy, di samping topiktopik di atas antara lain : Service catalogue management, Service level management (SLM), Capacity Management, Availability management, IT Service Continuity Management(ITSCM), Information Security Management (ISM), Supplier Management.

c. Service Transition menyediakan panduan kepada organisasi TI untuk dapat mengembangkan kemampuan untuk mengubah hasil desain layanan TI baik yang baru maupun diubah spesifikasinya ke dalam lingkungan operasional. Prosess yang dicakup dalam Service Transition yaitu Change Management, Asset \& Config Management, Release \& Deployment Management.

d. Service Operation adalah tahapan lifecycle yang mencakup semua kegiatan operasional harian pengelolaan layanan IT. Di dalamnya terdapat berbagai panduan mengelola layanan IT secara efisien dan efektif serta menjamin tingkat kinerja yang telah diperjanjikan dengan pelanggan sebelumnya [8] Proses yang dicakup dalam Service Transition yaitu: Event Management, Incident Management, Problem Management, Request Fulfillment, dan Access Management.

e. Continual Service Improvement (CSI) memberikan panduan penting dalam menyusun serta memelihara kualitas layanan dari proses desain, transisi dan pengoperasiannya. CSI mengkombinasikan berbagai prinsip dan metode dari manajemen kualitas, salah satunya adalah Plan-Do-Check-Act (PDCA) atau yang dikenal sebagai Deming Quality Cycle. Proses-proses dari CSI ini meliputi: Service Measurement \& Reporting dan 7-Step Improvement Process. 
Metode pengukuran tingkat kematangan pada ITIL menggunakan Maturity level. Terdapat lima maturity level pada ITIL, yaitu: Initial, Repeatable, Defined, Managed, dan Optimized. Maturity level dapat dilihat pada gambar 2 .

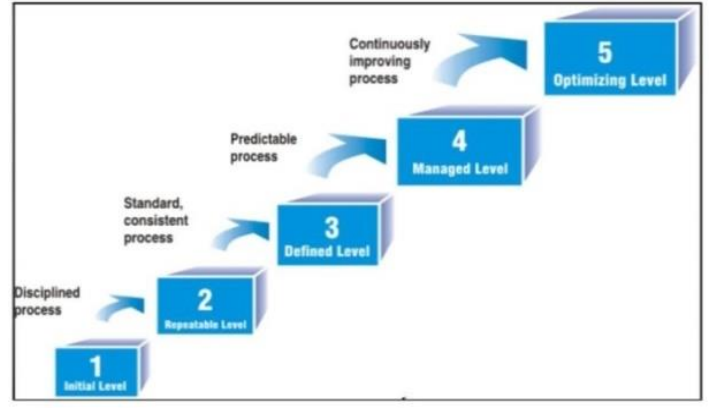

Gambar 2. Maturity Level

dapat menilai proses-proses TI yang dimilikinya dari skala 0 sampai 5. Deskripsi maturity model masing-masing [1] dapat di lihat pada tabel 1 monyai model kematangan (Maturity Model) mengontrol proses-proes TI dengan menggunakan metode penilaian (Scoring) sehingga suatu organisasi

Tabel 1 Deskripsi Maurity Model ITIL

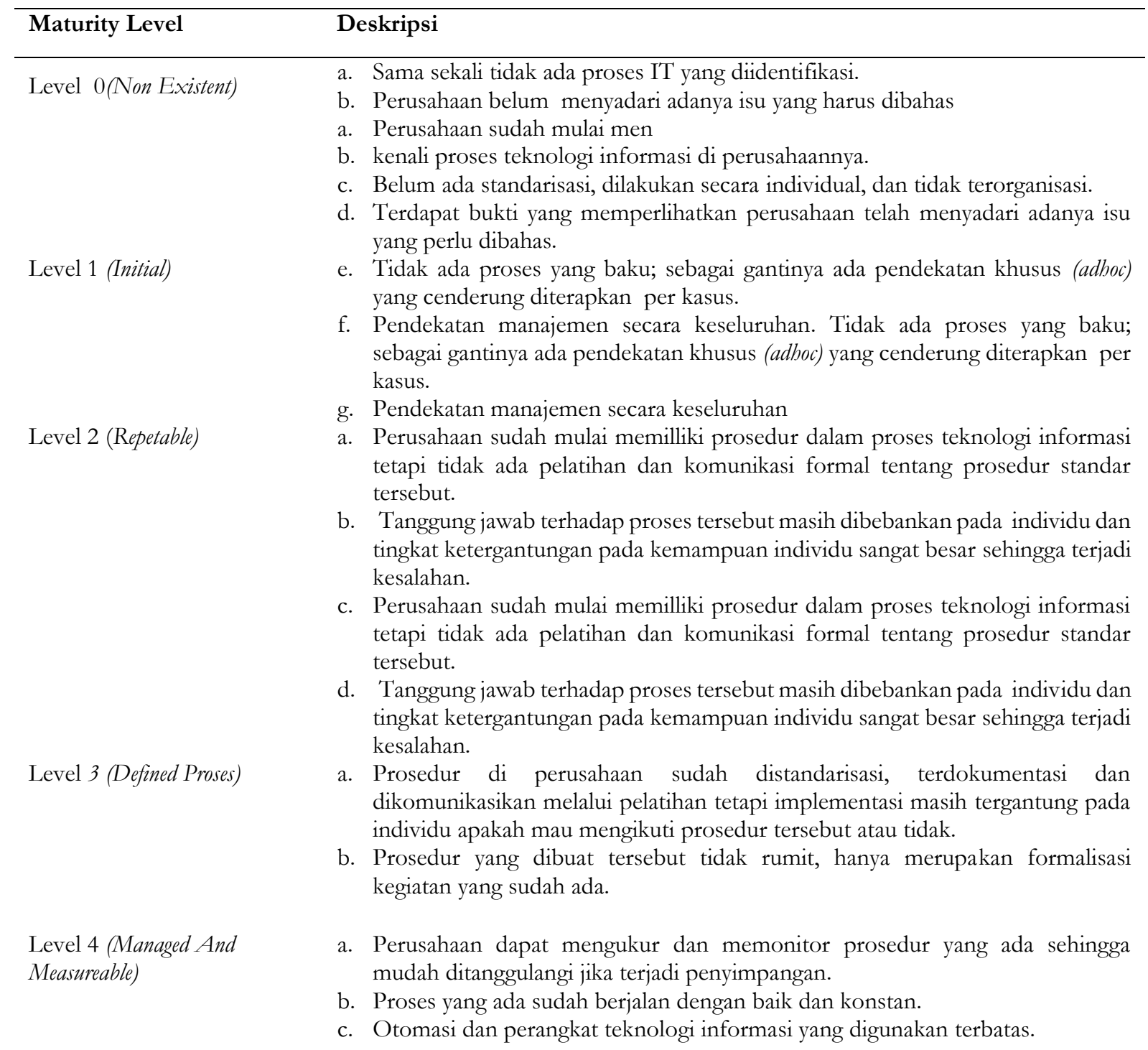


Level 5 (Optimized)

a. Proses yang ada sudah mencapai best practice melalui proses perbaikan yang terus menerus.

b. Teknologi informasi yang sudah digunakan terintegrasi untuk otomatisasi proses kerja dalam perusahaan, meningkatkan kualitas, efektivitas, serta kemampuan beradaptasi terhadap perusahaan

Kuesioner tersebut diisi berdasarkan hasil sistem informasi yang dilakukan merupakan kondisi riil pengamatan dan observasi yang dilakukan kemudian dari pengelolaan yang sedang dilakukan. Representasi dilakukan cross check dengan pihak manajemen tingkat kematangan ITIL dapat dilihat pada tabel 2.2 mengenai hasil yang didapatkan agar supaya penilaian

Tabel 2 Representasi Tingkat kematangan ITIL

\begin{tabular}{ll}
\hline Skala Indeks & Maturity Level \\
\hline $0-0.50$ & 0: Non Exsistent (tidak ada) \\
$0.51-1.50$ & 1: Initial (Inisial) \\
$1.51-2.50$ & 2: Repeatable (Pengulangan) \\
$2.51-3.50$ & 3: Defined Process (proses telah di definisikan) \\
$3.51-4.50$ & 4: Managed and measurable (Dikelola dan terukur) \\
$4.51-5$ & 5: Optimised (Optimalisasi) \\
\hline
\end{tabular}

\section{Metodologi}

Metodologi penelitian yang dilakukan memiliki beberapa tahapan. Tahap awal dari penelitian audit ini yaitu :

a. Identifikasi masalah, digunakan untuk mengidentifikasikan permasalahan- permasalahan yang ada di suatu perguruan tinggi/organisasi/perusahaan. b. Studi Literatur, yang digunakan dalam penelitian ini berupa jurnal, artikel, laporan penelitian, buku, tentang audit menggunakan framework ITIL V3, c. Pengumpulan data, teknik pengumpulan data yang digunakan adalah observasi, wawancara dan kuesioner dengan menerapkan instrumen framework ITIL V3.

d. Verifikasi dan validasi, tahap ini data yang telah terkumpul diverifikasi dan divalidasi sesuai dengan kebutuhannya, kemudian data tersebut dianalisis untuk mengetahui tingkat kematangan (Maturity Level), Gap anaysis dan rekomendasi.

e. Laporan audit, berisi hasil audit teknologi informasi, analisa dan rekomendasi perbaikan kualitas layanan teknologi informasi. Desain Penelitian ini dapat dilihat pada gambar 3

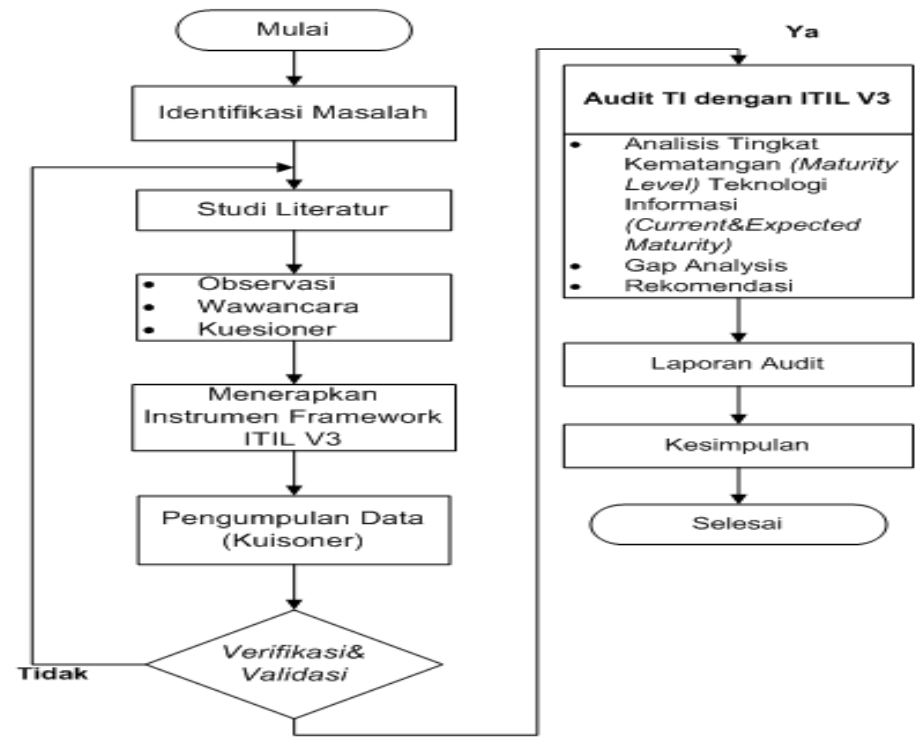

Gambar 3. Desain Penelitian 


\section{Hasil dan Pembahasan}

Hasil penelitian dari hasil observasi, wawancara dan kuesioner pada Perguruan Tinggi XYZ. Data kuesioner selanjutnya diolah dan di analisis menggunakan framework ITIL V3. Data hasil audit teknologi informasi di Perguruan Tinggi XYZ menggunakan framework ITIL V3 dapat di lihat pada tabel 3.

Tabel 3 Hasil Perhitungan Maturity Level

\begin{tabular}{llcc}
\hline No & Domain & Current Maturity & Expected Maturity \\
\hline 1 & Service Strategy (SS) & 3.83 & 4.56 \\
2 & Service Design (SD) & 4.08 & 4.78 \\
3 & Service Transition (ST) & 3.64 & 4.82 \\
4 & Service Operation (SO) & 4.05 & 4.48 \\
5 & Continous Service Improvement (CSI) & 4.09 & 4.69 \\
& Rata-rata & $\mathbf{3 . 9 4}$ & 4.67 \\
\hline
\end{tabular}

Berdasarkan hasil perhitungan maturity level pada tabel 4, diperoleh nilai current maturity terbesar berada pada domain Continous Service Improvement (CSI) dengan nilai sebesar 4,09 berada pada level 4 (Managed and Measureable). Nilai current maturity terkecil berada pada domain Service Strategy (SS) dengan nilai sebesar 3,83 berada pada level 3 (Define Process). Nilai rata-rata current maturity berada pada level 4 (managed and Measureable) dengan nilai sebesar 3,94, hal ini menunjukkan bahwa melalui kuesioner yang telah dibagikan bahwa Perguruan Tinggi XYZ sudah dapat mengukur dan memonitor prosedur yang ada sehingga mudah ditanggulangi jika terjadi penyimpangan serta proses yang sudah ada sudah berjalan dengan baik dan konstan. Diagram Perolehan maturity level dapat dilihat pada gambar 4 .

Gap analysis (analisa kesenjangan) adalah perbandingan nilai tingkat kematangan (Maturity Level) pada kondisi saat ini dengan nilai kematangan (Maturity Level) pada kondisi yang diharapkan. Hasil perolehan Gap Analisis pada penelitian ini dapat dilihat pada tabel 4.

Hasil analisis gap pada tabel 4, diperoleh gap analisis terbesar pada domain Service Transistion (ST) dengan nilai 1,18 sedangkan gap analisis terkecil pada domain Service Operation (SO) dengan nilai 0,43. Diagram perolehan gap analisis dapat di lihat pada gambar 5 .

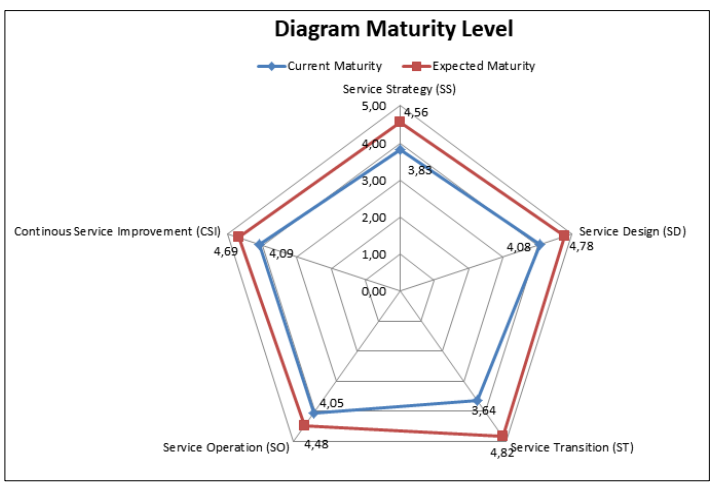

Gambar 4. Diagram Maturity Level

Tabel 4 Hasil Gap Analisis

\begin{tabular}{llc}
\hline No & Domain & Gap Analisis \\
\hline 1 & Service Strategy (SS) & 0.73 \\
2 & Service Design (SD) & 0.70 \\
3 & Service Transition (ST) & 1.18 \\
4 & Service Operation (SO) & 0.43 \\
5 & Continous Service Improvement (CSI) & 0.60 \\
& Rata-rata & $\mathbf{0 . 7 3}$ \\
\hline
\end{tabular}




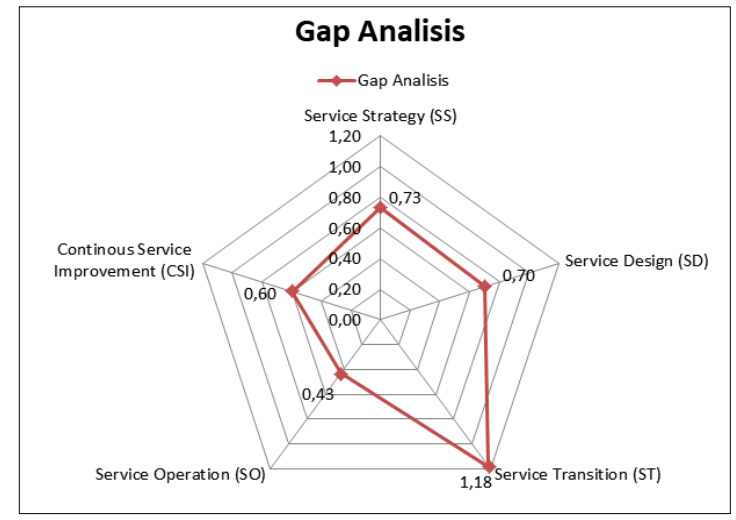

Gambar 5. Diagram Gap Analisis

Hasil rata-rata nilai gap analisi yang diperoleh sebesar 0,73 hal ini menunjukkan bahwa penerapan layanan TI sangat baik sehingga perlu membuat strategi peningkatkan kualitas layanan TI dengan lebih menjaga dan memelihara TI yang sudah ada, serta terus melakukan evaluasi secara berkala untuk perbaikan layanan TI secara berkelanjutan, dengan memberikan kemudahan akses layanan TI tersebut dimana saja bahkan dengan perangkat mobile. Manajemen juga perlu melakukan review terhadap penerapan layanan IT, bagaimana pengembangan layanan IT berdasarkan hasil uji coba layanan IT yang sudah berjalan.

Berdasarkan hasil perolehan maturity level dan analisis gap maka diperoleh beberapa rekomendasi untuk perbaikan kualitas teknologi informasi pada Perguruan Tinggi XYZ . Adapun rekomendasi perbaikan berdasarkan hasil audit dapat di lihat pada tabel 5 .

Tabel 5 Rekomendasi

\begin{tabular}{|c|c|c|c|}
\hline No & Domain ITIL V3 & Kondisi Existing & Rekomendasi \\
\hline 1 & Service Strategy (SS) & $\begin{array}{l}\text { Proses monitoring dan } \\
\text { evaluasi sudah dilakkan } \\
\text { namun belum dilakukan } \\
\text { secara rutin setiap satu bulan } \\
\text { sekali serta belum } \\
\text { terdokumentasi dengan baik } \\
\text { hasil dari monitoring dan } \\
\text { evaluasi. }\end{array}$ & $\begin{array}{l}\text { a. Manajemen perlu melakukan meeting minimal } \\
\text { sekali dalam sebulan sebagai sarana untuk } \\
\text { meningkatkan komunikasi yang efektif antara pihak } \\
\text { manajemen, pengembang IT dan unit/bagian } \\
\text { pengguna IT. } \\
\text { b. Manajemen perlu melakukan review terhadap } \\
\text { penerapan tata kelola TI yang ada sekarang untuk } \\
\text { mengetahui performa dari layanan TI gunakan } \\
\text { menetukan strategi yang tepat untuk peningkatan } \\
\text { kualitas TI ke depan yang lebih baik. }\end{array}$ \\
\hline 2 & Service Design (SD) & $\begin{array}{l}\text { Daftar atau list layanan IT } \\
\text { yang ada di Perguruan } \\
\text { TinggiXYZ sudah ada namun } \\
\text { belum terdokumentasi sesuai } \\
\text { dengan standar sehingga } \\
\text { terkadang masih mengalami } \\
\text { kesulitan dalam melihat } \\
\text { proses dari sisi tata kelola TI. }\end{array}$ & $\begin{array}{l}\text { a. Perlu dibuatkannya daftar layanan IT yang } \\
\text { sesuai dengan standar terhadap layanan IT yang } \\
\text { sudah ada apakah masih sesuai dengan kebutuhan } \\
\text { atau perlu adanya revisi terkait dengan design tata } \\
\text { kelola IT yang dapat mencakup strategi Perguruan } \\
\text { TinggiXYZ. } \\
\text { b. Perlu dilakukannya pengkategorian proses } \\
\text { implementasi yang dapat membantu manajemen } \\
\text { dalam melihat proses baik dari segi sistem informasi } \\
\text { dan tata kelola IT pada Perguruan Tinggi XYZ }\end{array}$ \\
\hline 3 & $\begin{array}{l}\text { Service Transition } \\
\text { (ST) }\end{array}$ & $\begin{array}{l}\text { Proses perubahan sistem ke } \\
\text { sistem baru sudah dilakukan } \\
\text { sesuai dengan kebutuhan user } \\
\text { namun belum } \\
\text { terdokumentasi. }\end{array}$ & $\begin{array}{l}\text { Perlu dibuatnya dokumen } \log \text { untuk mencatat hasil } \\
\text { monitoring dan evaluasi dari perubahan ke sistem } \\
\text { baru, adanya resiko dan peluang yang muncul }\end{array}$ \\
\hline 4 & $\begin{array}{l}\text { Service Operation } \\
(\mathrm{SO})\end{array}$ & $\begin{array}{l}\text { Sudah dilakukan monitoring } \\
\text { terhadap pengelolaan layanan } \\
\text { IT namun belum di lakukan } \\
\text { secara rutin serta belum } \\
\text { adanya progress report mengenai } \\
\text { dampak dari monitoring } \\
\text { tersebut. }\end{array}$ & $\begin{array}{l}\text { a. Manajemen harus rutin dalam melakukan } \\
\text { monitoring terhadap pengelolaan dan pemeliharaan } \\
\text { infrastruktur layanan IT sehingga } \\
\text { b. perlu dibuatkan log dokumen yang mencatat hasil } \\
\text { monitoring dari pemeliharaan layanan IT. data } \\
\text { dimana setiap proses back up data dapat } \\
\text { terdokumentasi sesuai dengan prosedur. }\end{array}$ \\
\hline
\end{tabular}


Sudah dilakukanya proses

back up data secara rutin

namun belum terdokumentasi

dengan baik.

$5 \quad$ Continous Service Improvement (CSI)
Sudah dilakukan tindakan perbaikan secara

berkelanjutan
Manajemen harus rutin melakukan monitoring dan kontrol terhadap penerapan IT guna menganalisa permasalahan serta mencari solusi untu melakukan tindakan perbaikan secara terus menerus guna peningkatan performa layanan IT

\section{Kesimpulan}

Berdasarkan hasil penelitian yang telah dilakukan di Perguruan Tinggi XYZ, diperoleh kesimpulan bahwa kemampuan perguruan tingggi $\mathrm{XYZ}$ dalam menerapkan layanan teknologi informasi sudah sangat baik dengan melihat nilai rata-rata gap analisis dari kelima domain yang terdapat pada ITIL V3 sebesar 0,73 .

Hal ini menunjukkan bahwa semua proses dan layanan teknologi informasi sudah berjalan dengat baik, sistem sudah terintegrasi, adanya kemudahan akses bagi user dimanapun berada serta perlu dilakukannya monitoring dan evaluasi layanan teknologi informasi secara berkelanjutan untuk menunjang kegiatan pada Perguruan Tinggi XYZ.

\section{Daftar Pustaka}

[1] Abdul Kadir. 2005. Pengenalan IT. Yogyakarta 2005 An Introductory Overview of ITIL V3, A High Level Overview of the IT Infrastructure Library, itSMF Ltd, 2007

[2] Dewi Kumala Tri Meva .2013. Meningkatkan Keunggulan Kompetitif Perusahaan Dengan Penerapan Knowledge Management (Manajemen Pengetahuan). Malang

[3] Ian MacDonald. 2010. ITIL Process Asessment Framework.

[4] Andi Jogiyanto. 2011. Tata Kelola Teknologi Informasi . Yogyakarta : Andi
[5] OGC, 2007, The Official Introduction to the ITIL Service Lifecycle, TSO, London.

[6] Rasa, G., S. Jagadheesh Kumar, and RSD Wahida Banu. "Release and deployment management using ITIL." Global Journal of Computer Science and Technology (2010)

[7] Rudd, Colin, and Gary Hodgkiss. "An Introductory Overview of ITIL, itSMF." UK: The Stationery Office (2004).

[8] Sahuleka, Peter Javier. Analisis Kualitas Layanan Teknologi Informasi dengan Menggunakan Framework Information Technology Infrastructure Library Version 3 (ITIL V. 3) Service Operation: studi kasus PT. PLN (Persero) Distribusi Jateng \& DIY. Diss. Program Studi Sistem Informasi FTIUKSW, 2016.

[9] Taufik,Ichsan."Perancangan IT Governance Layanan Akademik Menggunakan Framework Information Technology Infrastrukture (ITIL) versi 3 (Studi Kasus : UIN SGD Bandung).'Jurnal ISTEK 5.1-2(2015).

[10] Utami, Rachmadini Pratiwi, Eko Darwiyanto, and Ibnu Asror. "Audit Infrastruktur Teknologi Informasi dengan Standar Information Technology Infrastructure Library (ITIL) V. 3 Domain Service Strategy dan Service Design (Studi Kasus: Igracias)." Bandung: Telkom University (2014).

[11] Weber, Ron, 2000, Informatioin System Control and Audit, The University of Queensland, Prentice Hall Inc. 